POLSKA AKADEMIA NAUK —ZAKŁAD BADANIA SSAKOW

A C T A T H E R I O

VOL. III, 3.

BIAŁOWIEŻA

15. X. 1959

Adam K R Z A N OW S K I

\title{
Some Major Aspects of Population Turnover in Wintering Bats in the Cave at Pulawy (Poland)
}

\section{Ważniejsze aspekty zimowej dynamiki populacji nietoperzy w jaskini w Pulawach}

\footnotetext{
I. Introduction

II. Material and methods

IiI. Results and discussion

IV. Summary

References

Streszczenie
}

\section{INTRODUCTION}

The investigations described below were undertaken in view of the lack of analogical publications based on comprehensive material. In the years $1951 / 52-1955 / 56$, during five successive winter seasons (October - April) 602 visits were made (average 1.67 per day) to the artificial cave at Pulawy and the bats found there were marked. I laid chief emphasis on: 1) Observing and following up the frequentation of different species in the hibernation period; 2) Observing and following up possible quantitative variations in the relation of males: females during the above period. 
I must, however, give warning that no generalisations should be made on the basis of my observations.

\section{MATERIAL AND METHODS}

Over the period of the above 5 years, 10 species of bats were observed in the cave (Table 1).

Table 1.

Bats encountered in the cave.

\begin{tabular}{|c|c|c|c|}
\hline No. & Species & Encounters & Individuals \\
\hline 1 & Myotis nattereri $\mathrm{Kuhl}$ & 480 & 366 \\
\hline 2 & Plecotus auritus Linnaeus & 279 & 111 \\
\hline 3 & Barbastella barbastellus $\mathrm{Schreber}$ & 165 & 69 \\
\hline 4 & Myotis myotis Borkhausen & 108 & 69 \\
\hline 5 & Eptesicus serotinus $\mathrm{S} \mathrm{chr}$ eber & 77 & 29 \\
\hline 6 & Myotis daubentoni $\mathrm{Kuhl}$ & 23 & 17 \\
\hline 7 & Myotis mystacinus $\mathrm{Ku} \mathrm{h} \mathrm{l}$ & 8 & 2 \\
\hline 8 & Myotis dasycneme $\mathrm{B}$ o i $\mathrm{e}$ & 1 & 1 \\
\hline 9 & Myotis bechsteini $\mathrm{Kuhl}$ & 1 & 1 \\
\hline \multirow[t]{3}{*}{10} & Pipistrellus pipistrellus $\mathrm{Schreber}$ & 1 & 1 \\
\hline & Species indeterminatae ${ }^{1}$ ) & 91 & - \\
\hline & Total & 1234 & 666 \\
\hline
\end{tabular}

1) The species was not determinable, if a bat was hidden too far inside the crevice to be captured or if it was flying round the cave.

The difference between the number of encounters and the numbers of individuals arises from the fact that the same individual was sometimes found several times over. As a rule the bats hiding in crevices were not visible, so I revealed their presence by inserting a flexible wooden rod into the crevices; the bat when touched usualjy squeaks, thus betraying its presence. I then ciragged it out by means of a wire hook. Fuller details of the rings slipped on the fore-arm of the bats is given in the work by Kowalski et al. (1957); from March $1955 \mathrm{I}$ began using ear tags of my own design (K r z an ow s k i, 1956b).

\section{The climate at Pulawy (ace. to Pan owic z, 1949)}

The climate at Puławy is typical of that prevailing in Central Poland, and constitutes the transition stage between the oceanic climate of Western Furope and the continental climate of Eastern Europe. This is usually manifested in the wide variations in temperature. First and last ground frosts: 20. IX. - 11. XI. and 25. III. - 24. V. There are on the average 177 days in the year without frost, with fluctuations between 133 and 218 days. Average annual tcmperature amplitude: 21.8. Prevailing winds are NW, W and SW: the figure for these winds is 39 as compared with 29 for easterly winds (Table 2). 


\begin{tabular}{|c|c|c|c|c|c|c|c|c|c|}
\hline 竘 & $\stackrel{\infty}{\stackrel{\infty}{*}} \stackrel{0}{\dot{0}}$ & i் & : & $\stackrel{\sim}{\sim}$ & $\stackrel{?}{\dot{q}}$ & $\stackrel{a}{\grave{0}}$ & $\begin{array}{c}3 \\
\bar{n} \\
8 \\
8\end{array}$ & 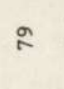 & \\
\hline$\vec{x}$ & $\stackrel{9}{\dagger} \stackrel{\infty}{\leftarrow}$ & $\hat{\dot{\omega}} \stackrel{\infty}{\stackrel{\infty}{i}}$ & $\begin{array}{l}\infty \\
\stackrel{0}{i} \\
\stackrel{i}{i}\end{array}$ & iे & ' & $\stackrel{\sim}{i}$ & $\stackrel{\square}{\check{n}}$ & & i \\
\hline$\vec{x}$ & $\stackrel{n}{i} \stackrel{g}{=}$ & $\stackrel{9}{\stackrel{\sim}{\sim}}$ & $\stackrel{\vec{j}}{\dot{i}} \hat{i}$ & $\stackrel{\infty}{\stackrel{\sim}{1}}$ & ' & $\stackrel{\leftrightarrow}{\ddot{\sim}}$ & $\stackrel{0}{\dot{i}} \underset{\stackrel{\infty}{\infty}}{n}$ & 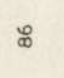 & $\dot{\mathrm{i}}$ \\
\hline$\star$ & 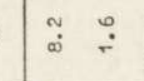 & iे & $\stackrel{i}{i}$ & $\stackrel{+}{\pi}$ & $\ddot{n}$ & $\stackrel{\infty}{i}$ & 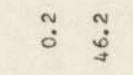 & $\approx$ & $\hat{i}$ \\
\hline 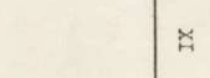 & 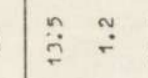 & $\hat{\dot{\omega}} \stackrel{\circ}{\mathrm{r}}$ & 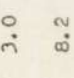 & 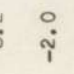 & $\stackrel{n}{i}$ & $\hat{o}$ & $1 \stackrel{0}{\dot{n}}$ & $\stackrel{\infty}{\sim}$ & $\dot{i}$ \\
\hline 莒 & $\stackrel{+}{\check{\leftarrow}}=$ & 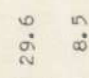 & $\stackrel{\infty}{\stackrel{\infty}{\infty}} \stackrel{\circ}{\stackrel{5}{\circ}}$ & $\stackrel{\infty}{i}$ & $\hat{\alpha}$ & ' & 1 हं & & $\dot{i}$ \\
\hline$\stackrel{5}{5}$ & 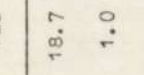 & $\ddot{\dot{m}}$ : & $\therefore \stackrel{i}{+}$ & in & $\stackrel{n}{\tilde{m}}$ & ' & $1 \stackrel{0}{\stackrel{\omega}{\omega}}$ & & $\stackrel{\text { ก }}{2}$ \\
\hline$\underset{\widetilde{\sigma}}{\mathbb{J}}$ & $\overline{2}$ & $\stackrel{0}{\stackrel{\infty}{\infty}}$ & $\overrightarrow{\dot{\omega}} \stackrel{\sim}{\stackrel{5}{c}}$ & $\stackrel{\infty}{=}$ & $\stackrel{\infty}{\leftarrow}$ & I & $1 \stackrel{+}{\dot{E}}$ & & $\hat{i}$ \\
\hline$\nsubseteq$ & $\stackrel{\circ}{\check{C}}$ & $\hat{i} \dot{N}$ & $\vec{*} \stackrel{a}{\stackrel{i}{i}}$ & $\dot{\infty}$ & $\stackrel{\circ}{n}$ & $\stackrel{\overrightarrow{0}}{0}$ & $1 \stackrel{0}{i}$ & & $\stackrel{\text { I }}{ }$ \\
\hline 节 & $\stackrel{\square}{\circ} \stackrel{0}{\circ}$ & 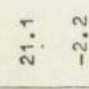 & $\stackrel{\text { ì }}{i}$ & : & $\stackrel{n}{0}$ & $\dot{n}$ & $1 \stackrel{+}{\circ}$ & & $\hat{\text { i }}$ \\
\hline$\underset{\widetilde{J}}{\mathbb{S}}$ & $\stackrel{\infty}{=} \stackrel{\circ}{-}$ & 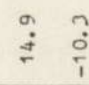 & $i_{i}^{3}:$ & 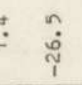 & $\stackrel{\sim}{\circ}$ & $\stackrel{9}{\check{1}}$ & $\stackrel{\circ}{\dot{n}}$ & & $\hat{i}$ \\
\hline$\Rightarrow$ & 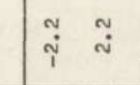 & $\stackrel{+}{\dddot{*}}$ & iे & 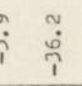 & 1 & $\stackrel{\sim}{\sim}$ & $\stackrel{n}{\underset{\sim}{\sim}} \stackrel{0}{\dot{\infty}}$ & & $\stackrel{\circ}{\sim}$ \\
\hline$H$ & $\bar{i} \stackrel{4}{i}$ & $\stackrel{0}{\dot{n}} \stackrel{0}{\dot{0}}$ & $\begin{array}{l}0 \\
\dot{0} \\
\dot{i}\end{array}$ & पे & , & $\stackrel{\infty}{\sim}$ & $\stackrel{\circ}{\circ}$ & $\stackrel{\varpi}{\circ}$ & $\stackrel{a}{i}$ \\
\hline 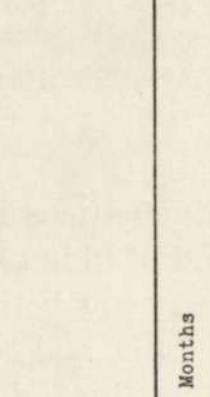 & 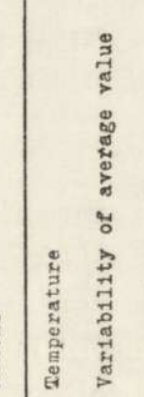 & 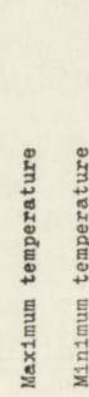 & 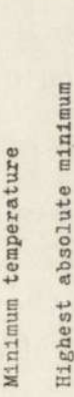 & 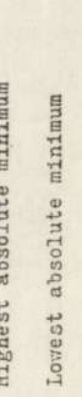 & 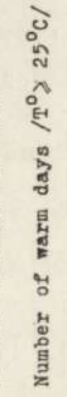 & 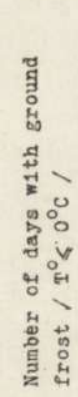 & 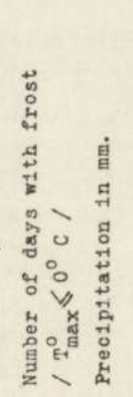 & 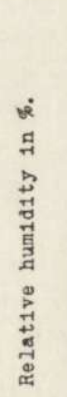 & $\dot{g}$ \\
\hline
\end{tabular}




\section{Description of cave}

The cave is situated at $51^{\circ} 25^{\prime} \mathrm{N}$ and $21^{\circ} 57^{\prime} \mathrm{S}$. Height above sea level $130-135 \mathrm{~m}$. The site lies in the territory forming the transition between the hilly loess area of the Lublin Highland and the sandy lowlands of Mazovia, on the southern loess slope. Its lower entrance is about $1 \mathrm{~m}$. above the base of the slope and about $1.5 \mathrm{~m}$. above the very variable level of the Vistula riverside pond (old river bed), and about $12 \mathrm{~m}$. distant from it. This cave is of artificial construction, but the date and purpose of its construction are unknown; it was probably made in the XVIII century. Its walls are formed by limestone slabs, and the roof is loess in the highest places. The large number of deep crevices give it the appearance of a tectonic cave (Plate IV,

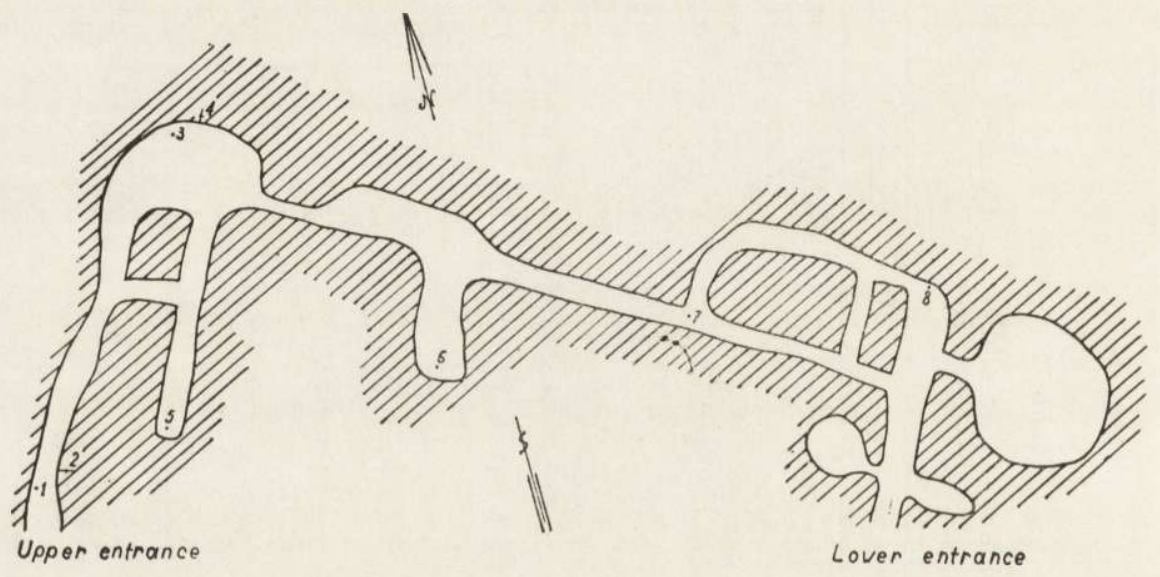

Fig. 1. Sketch of cave. $1 \mathrm{~cm} .=6 \mathrm{~m}$.

Phot. 1 and 2). A sketch is given of the lay-out of the cave (Fig. 1). The area in the immediate vicinity of the cave is thickly wooded, with dense undergrowth (Park of the Agricultural Institute). In addition to the riverside pond referred to above, the Vistula flows about $1 \mathrm{~km}$. away from the cave. A small alluvial-type forest is situated $1 / 2 \mathrm{~km}$. away. The more distant territory is covered by a large number of oak- and pine forests. Loess and the fertile muds on the Vistula river banks cause the vegetation here to be very luxuriant and varied. The nearest cave (artificial, in a quarry) is situated 10 $\mathrm{km}$. away Sc: $1 \mathrm{~cm}$. $=6 \mathrm{~m}$.

\section{Climate in the cave}

As will be seen from Table 3, the temperature fluctuations in this cave are greater than is usually the case in this kind of hiding-place. The reason for this is the fact that there are entrances at both ends cf the cave (about $2 \times 1.5 \mathrm{~m}$ ) lying at different heights, and several small window-like openings. I have often felt a distinct draught 
there. These properties qualify the cave as dynamic cold (V a n Nie uwenhoven, 1956). Measurement of temperature and relative humidity in which the bats lived was generally impossible, as the crevices were too deep and twisted to permit of measuring instruments being inserted. It is, however, certain that the climatic fluctuations were slighter within the crevices than outside. During hard winters hoar frost appeared on the walls of the cave, only the small and most deeply situated places in the cave being free from it. As is shown by Table 3, almost no temperatures below $0^{\circ} \mathrm{C}$. were noted in the cave, but I presume that this was merely the result of the exceptionally mild winter of $1956 / 7$, especially the second half.

The following conclusions can be drawn from Table 3 :

Table 3.

Measurements of temperature and relative humidity in interior of cave.

\begin{tabular}{|c|c|c|c|c|c|c|c|c|c|c|}
\hline 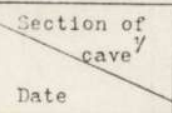 & 1 & 2 & 3 & 4 & 5 & 6 & 3. & 8 & 9 & $\begin{array}{c}\text { Outside } \\
\text { cave }\end{array}$ \\
\hline 16. X. 1956 & 10.3 & $10: 1$ & 9.5 & 10.0 & - & 9.6 & 8.6 & 8.4 & 7.8 & 9.1 \\
\hline 17.XI. 1956 & 6.4 & 6.0 & 6.4 & - & 6.4 & 6.0 & 5.3 & 4.7 & 4.6 & 5.5 \\
\hline 17.XII. 1956 & 6.9 & 5.5 & 5.6 & - & 6.0 & 5.6 & 6.2 & 5.0 & 4.0 & 7.5 \\
\hline 15. I. 1957 & 0.3 & 2.4 & 2.5 & - & 3.5 & 1.9 & -0.9 & 0.1 & -2.6 & -7.1 \\
\hline 28.II. 1957 & 2.6 & - & 3.0 & - & - & 2.3 & 0.4 & - & 0.6 & -2.3 \\
\hline 10.1V. 1957 & 10.4 & - & 8.5 & - & - & 6.6 & 6.8 & 5.7 & 8.0 & 8.3 \\
\hline 4. V. 1957 & 11.6 & - & 9.2 & - & 9.4 & 8.0 & 7.8 & 7.6 & 9.2 & 12.5 \\
\hline 28.II. 1957 & - & - & 906 & - & - & - & - & - & - & $68 \%$ \\
\hline 10.IV. 1957 & 53\% & - & $67 \%$ & - & - & $81 \%$ & $77 \%$ & $85 \%$ & $72 \%$ & $37 \%$ \\
\hline 4. v. 1957 & $69 \%$ & - & 895 & - & $93 \%$ & $97 \%$ & $95 \%$ & $97 \%$ & $81 \%$ & $67 x$ \\
\hline
\end{tabular}

1) Figures indicate localisation marked on sketch of cave (Fig. 1).

1) The temperature of the cave is very variable, depending on the localisation of measurement and the time of the year.

2) The temperature at the upper entrance is higher than at the lower.

3) In the winter the temperature in the cave may fall below $0^{\circ} \mathrm{C}$.

4) The relative humidity is variable, but considerably higher than the external one. 
5) The relative humidity of the lower part of the cave is greater than in the upper parts.

The walls of the cave are everywhere dry and only in one place, over a surface of about 2 sq. m., do drops of water sometimes collect on the ceiling, but they never fall. Sleeping bats are only exceptionally covered in dew in this cave. The cave is sometimes relatively light. This takes place when the sun, shining low above the horizon, sends its beams so that they are reflected from the surface of the riverside pond straight into the upper entrance. It is then possible, Fig. 2. Diagram of minimum and maximum night temperatures and results of visites during period from 1952-1956.
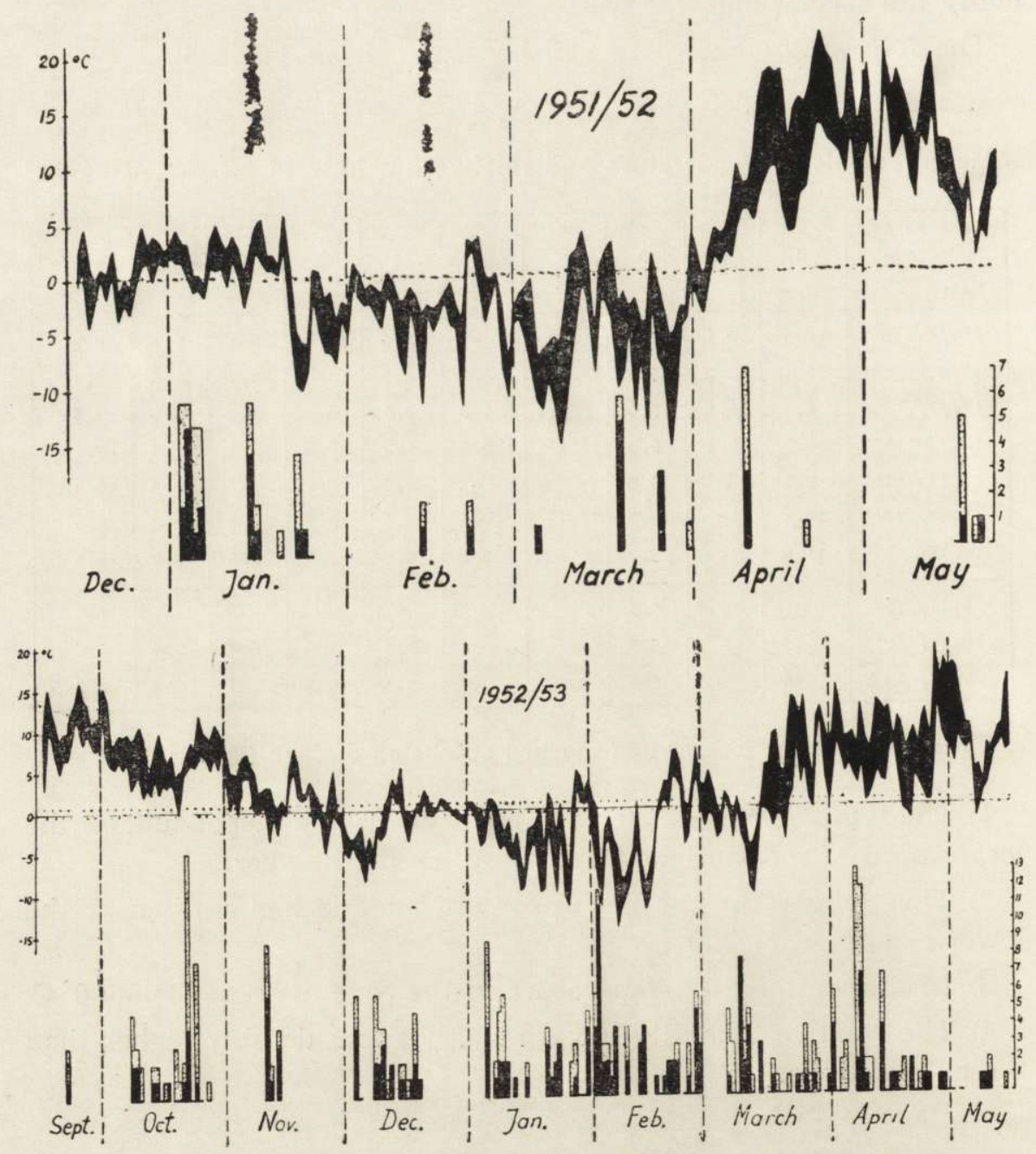

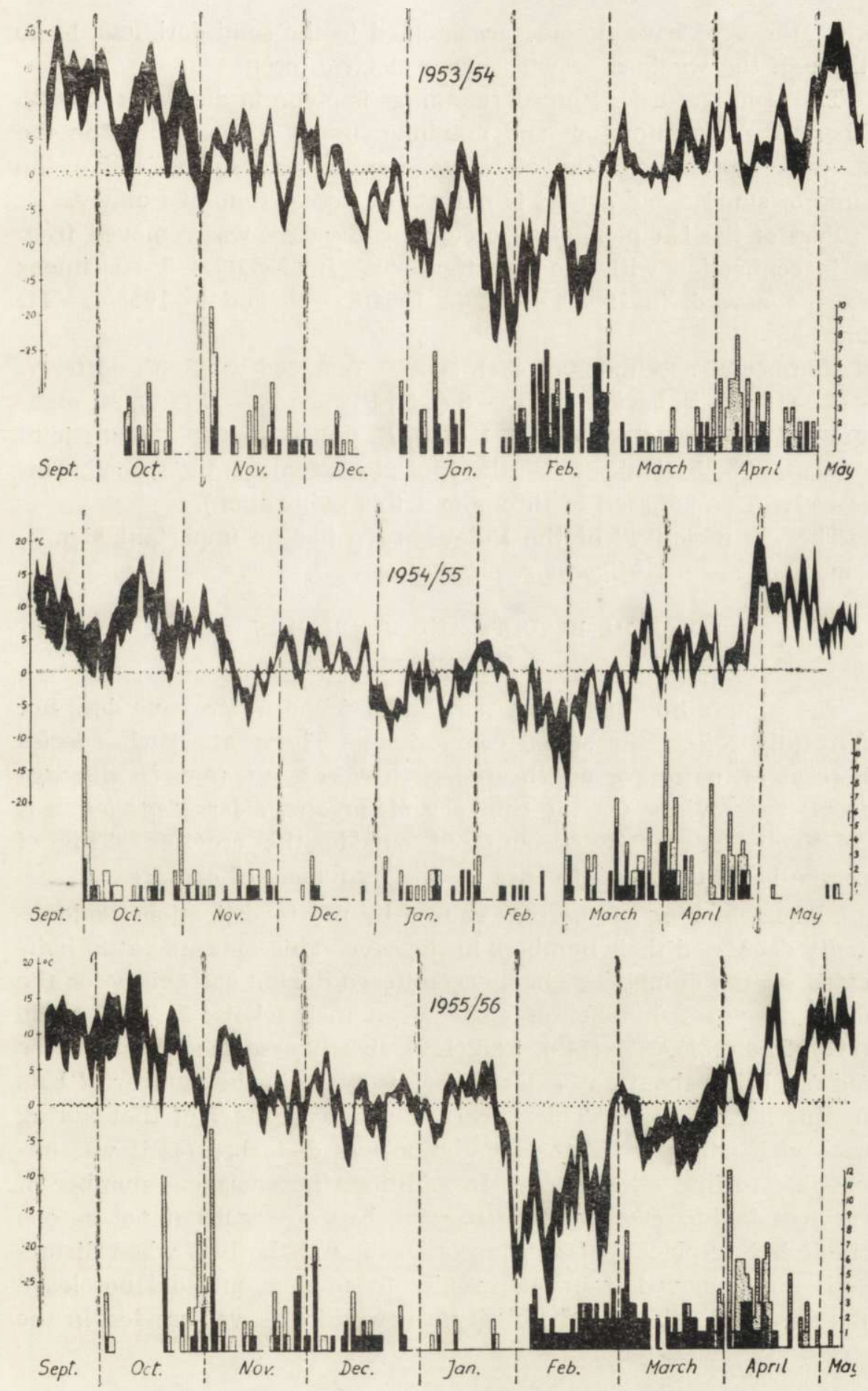
after the eyes have become accustomed to the semi-darkness, to go through the whole cave without an electric torch.

The temperature of the surroundings is given in diagrams (Fig. 2). These are the minimum and maximum night temperatures on the exterior of the cave (period between sunset and sunrise). By the time of sunrise and sunset is meant the actual time at Puławy.

Part of the bat population occupying the cave was removed from it in connection with the investigations. In $19.2 / 3--7$ specimens were removed, in $1953 / 4-12$, in $1954 / 5-20$ and in $1955 / 6-11$; total 50 .

Number of specimens of each species removed were: $M$. nattereri -- 29 (18:11), B. barbastellus - 8 (3:5), P. auritus - 7 (2:5), M. myotis $-4(1: 3)$, E. serotinus - $1(0: 1), P$. pipistrellus - $1(1: 0)$; joint sex ratio 25:?5. (Males given the first place, females the second. This order will he adhered to throughout this publication).

The ,,artificiality" of the Puławy cave has no important significance for my investigations.

\section{RESULTS AND DISCUSSION}

\section{a. General section}

The composition of the bat population found in the cave does not faithfully reflect the actual composition. There are such species here as $M$. nattereri, which are very difficult to find or dislodge from the crevices. On the contrary $M$. myotis, a large species, was relatively frequently encountered outside the crevices. This of course has a certain influence on the frequency of capture.

The frightening of the bats caused by my investigations undoubtedly decreased their numbers in the cave. This appears to be indicated by the numbers of bats encountered during each visit, for the different years (number of visits given in brackets: 2.87 (23), 2.66 (119), 2.18 (131), 1.52 (149), 1.88 (180). In any case the investigations did not bring about any catastrophic decrease in the number of bats in this hiding-place. This is certainly due to the fact that during each visit only part of the population was disturbed (as it was impossible to find all of them). In addition, the enormous number of crevices in this cave might cause the bats to regard it not as one single hiding-place, hut a group of them, and the bats when disturbed simply moved from one crevice to another, and did not leave the cave altogether. Undoubtedly a new balance was created in the 
cave after a certain time, since a new generation of bats takes up its habitation in the cave every year, and are at first unaware of any disadvantages to this hiding-place, and in the same way part of the old generation disappears from the cave every year, i. e. bats which would otherwise more or less avoid the place.

The removal of the 50 bats referred to above did not therefore have any important influence on results, as they represented a small part only of the population as a whole.

It proved impossible to reach any conclusions from a single visit on account of the small numbers obtained: out of 602 visits, on 137 occasions no specimens were found at all, the average number of bats found during one visit was 2.05 , and finding 15 bats constituted a record. On this account not only were visits aggregated into 2-week or eien larger series, but aiso analogical periods in the different years of observation were considered jointly, and averages calculated from them. It is true that the differences between the results of different years were sometimes fairly considerable, but the general tendency of the course followed by the number of encounters was similar. Differences were rather the result of the insufficient numbers available.

Interrupted hibernation: What is surprising about records of the visits is the unusual variability of the hat population. Despite the winter it seldom happened that the given individual was observed during both of two successive visits. The average period between encounters of the same individual was usually several hundred days. Only very severe frosts, which made exchange with the populations from outside impossible, maintained stability of population. This variability cannot be explained by the bats having heen frightened; since frightening the bats away does not explain the appearance of new individuals. These latter chiefly arrived from the outside of the cave, and only a small part of their numbers could come from crevices which had not been examined. The reserve of bats which is concealed in these crevices is far too small to mainiain this exchange for a long period.

No dependence of the appearance of bats on the exterior temperature was found. It is however possible that the fault here lies with the small numbers of bats found during each visit.

Quantitative sex-ratio: In the majority of works (cf. e. g. Mohr, 1952) a preponderance of males is found among the 
hibernating bats in caves. My investigations have not, however, confirmed this. I would emphasise here that I have only taken under consideration the actual individuals, i. e. I did not count the 2nd, 3rd etc. encounter with the same individual. (The number of encounters is given in brackets). The unrelated figures by the side of the percentages indicate the number of specimens of bats.

1. Myotis nattereri: $194: 168$, i. e. $53.6 \%$ males $(257: 219$, i. e. $54.0 \%$ males). Deviation from ratio $1: 1$ is statistically insignificant. In different seasons there are considerable fluctuations in favour of one or the other sex.

2. Plecotus auritus: $66: 38$, i. e. $63.5 \%$ males $(165: 107$, i. e. $60.7 \%$ males). Here also seasonal fluctuations are considerable, but males ure always predominant. $\mathrm{P}<0.01$, and the deviation from the ratio $1: 1$ is therefore statistically significant.

3. Barbastella barbastellus: $33: 35$, i. e. $48.5 \%$ males $(71: 93$, i. e. $43.3 \%$ males). Fluctuations in different seasons are large, possibly on account of comparatively small numbers.

4. Myotis myotis: $22: 47$, i. e. $31.9 \%$ males $(43: 64$, i. e. $40.2 \%$ males). $\mathrm{P}<0.01$, and the deviation is therefore statistically significant.

5. Eptesicus serotinus: $14: 14$, i. e. $50.0 \%$ males $(49: 27$, i. e. $64.5 \%$ males).

6. Myotis daubentoni: $13: 5$, i. e. $72.2 \%$ males $(17: 6$, i. e. $73.9 \%$ males). Deviation from ratio $1: 1$ is almost significant since $P=0.06$.

As will be seen, in three cases the ratio is as circa 1:1, in two cases males predominate (in one of these cases the position is doubtful, since based on small numbers), and in one case the females predominate. However, as shown by the diagrams, the various species reveal characteristic (and often widely differing) regular changes in sex-ratio, depending on the season of the year, i. e. inside the cave. The value of the above averages is therefore problematical. Neither is it easy to say to what extent my observations reflect the real ratios outside the cave, e. g. the average sex-ratio of $M$. nattereri rises to $8: 1$ in the autumn, and alters in the spring to $1: 2$ ! It is of course clear that variations in sex-ratio of 16 times as much cannot occur in nature. The dynamic approach to these problems has not, however, for some reason found favour with investigators of bats.

\section{b. Detailed section}

1. M. nattereri: As is clear from Fig. $3 \mathrm{a}$, it occurs in this hidingplace chiefly in autumn and spring. It probably arrives here in the 


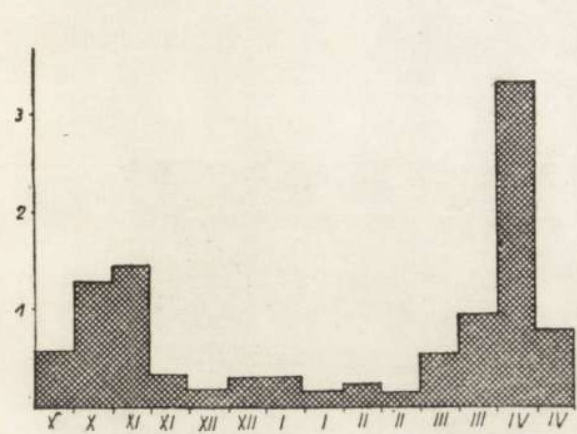

a.

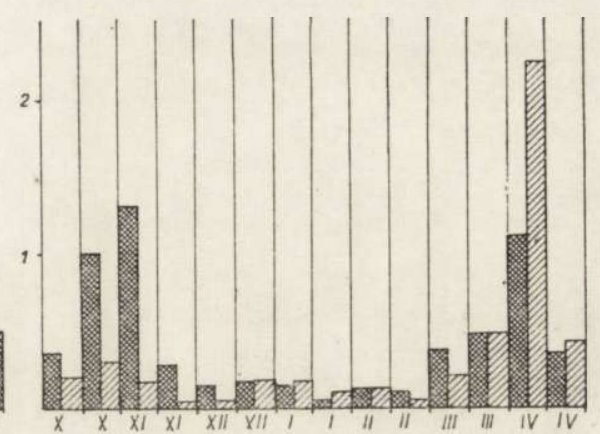

b.

Fig. 3. Nyotis nattereri $\mathrm{Kuhl}$; a - Frequentation (specimens per visit). h - - Frequentation (males and females per visit; males marked by crisscross lines, females by oblique lines).

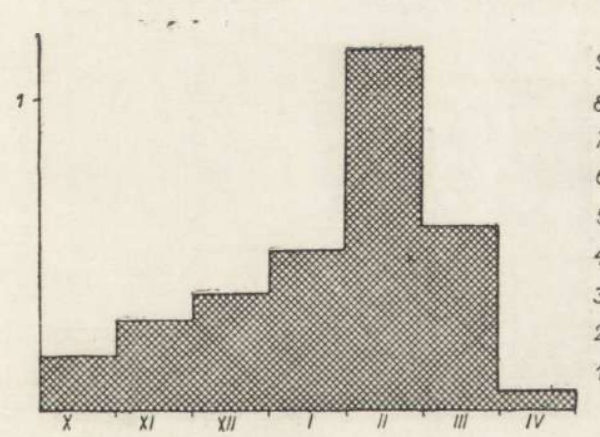

a.

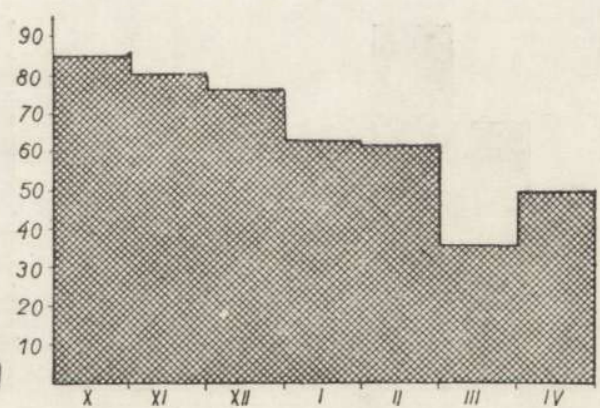

b.

Fig. 4. Plecotus auritus L.; a - Frequentation (specimens per visit). b Males (per cent).

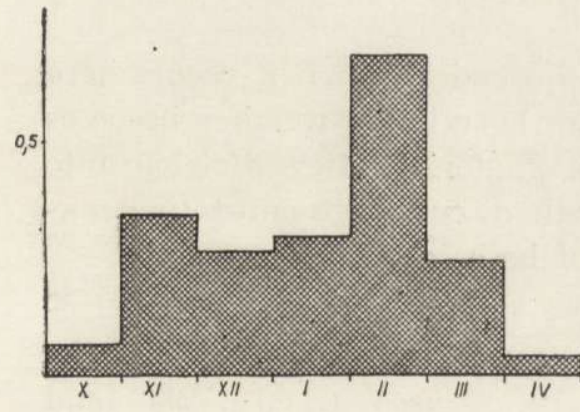

a.

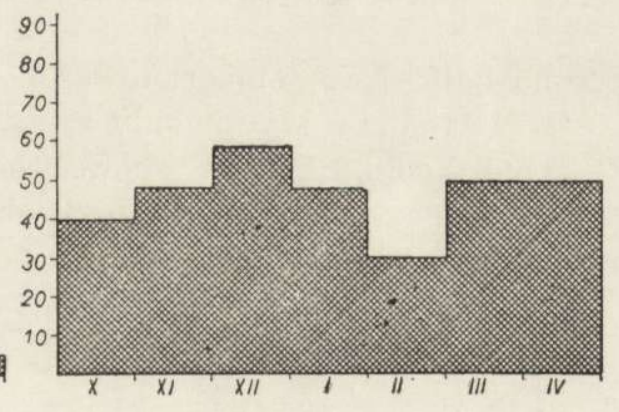

b.

Fig. 5. Barbastella barbastellus $\mathrm{S} \mathrm{ch} \mathrm{re} \mathrm{b.;} \mathrm{a} \mathrm{-} \mathrm{Frequentation} \mathrm{(specimens} \mathrm{per}$ visit). $b-$ Males (per cent). 


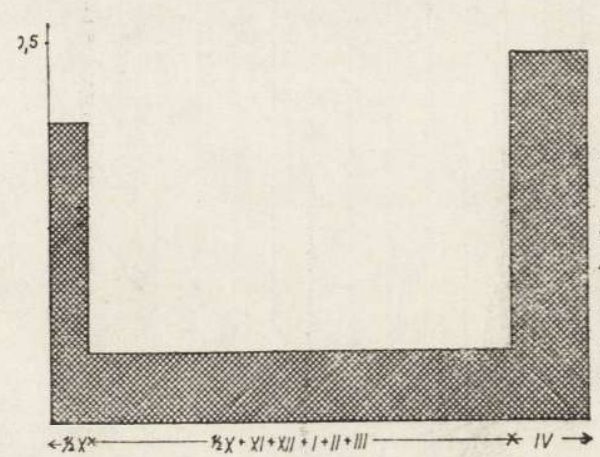

a.

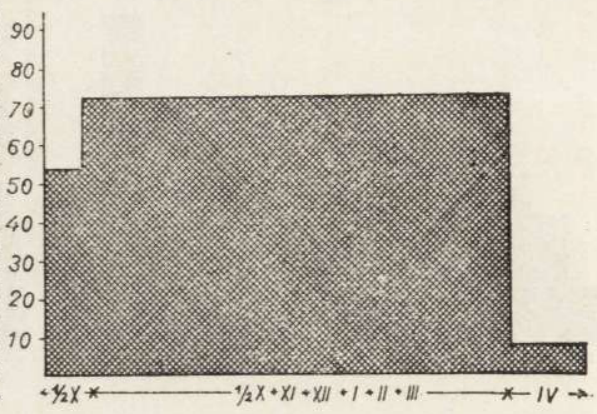

b.

Fig. 6. Myotis myotis B orkh.; a - Frequentation (specimens per visit). b - Males (per cent).

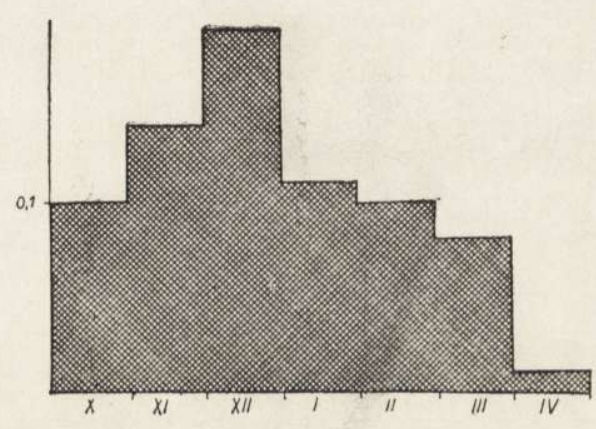

Fig. 7.

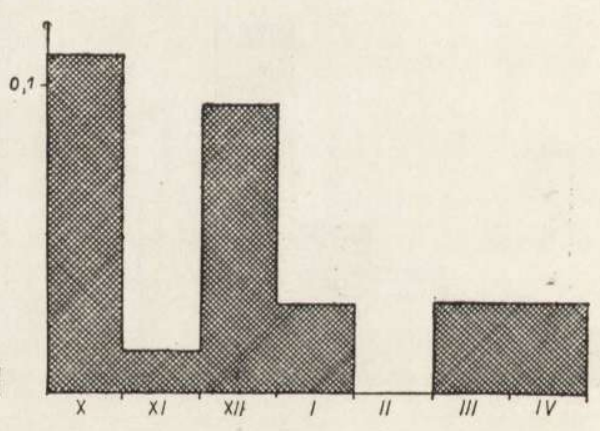

Fig. 8.

Fig. 7. Eptesicus serotinus $\mathrm{Sch} \mathrm{reb}$; Frequentation (specimens per visit). Fig. 8 Myotis daubentoni $\mathrm{Kuhl}$; Frequentation (specimens per visit).

second half of September; towards the end of April it occurs here so rarely that by May it only appears here if the weather becomes €xtremely cold. Fig. $3 \mathrm{~b}$ shows the material after division into sexes. As previously emphasised when discussing quantitative sexratios, the dynamics of appearance of both sexes differ greatly.

2. P. auritus: Contrary to the above species, this bat is most frequently here in the winter, which is probably connected with its great powers of resistance to low temperatures (B e ls, 1952 and many others). Certain individuals, during the period of sharp frosts, are encountered here on even 40 successive occasions, thus giving rise to the February peak number of bats encountered (Fig. 4a). 
Fig. $4 \mathrm{~b}$ shows that the percentage of males in relation to the total number encountered decreases markedly from October to March.

3. B. barbastellus: This also, as shown by Fig. $5 \mathrm{a}$, is here as a winter species known for its resistance to cold. Although the wave of frosts in the seasons $1952 / 3$ and 1953/4 made this bat take refuge in the cave, the great frosts in February 1956 did not bring about an influx into this cave. This species does not exhibit any regular fluctuations in the percentage of males encountered (Fig. 5b).

4. M. myotis: Like $M$. nattereri, this is an autumn-spring species. This is easily understandable in view of the fact that the cave under investigation is regarded as cold, and $M$. myotis has high thermal requirements. It is interesting to note that in Puławy this species is close to the geographical limit of its range (e. g. W a ł e c k i, 1881), and does not appear, at least as far as observations hitherto made have shown, to undertake any migration, as individuals of this species from Southern Poland do, a very considerable part of their numbers moving in the winter beyond the Carpathians (my cwn investigations, partly published in the work $\mathrm{Kowalski}$ et a]., 1957).

This species moves into the cave considerably earlier than $M$. nattereri, as the maximum number of encounters with it falls in the first half of Octoher, and in the stcond half of the month we have its winter minimum (Fig. 6a). The fact of its move to the cave in the spring later than $M$. nattereri would appear correlated to this: in March this bat is not encountered more often here than in the winter; in addition, it remains here longer in the spring than $M$. nattereri, since it is not less frequently encountered here in the second half of April than in the first. If the weather is cold in May, it continues to remain in the cave.

In this species also we can observe interesting and radical variations in the quantitative sex-ratio: the females predominate by 10 times as much over the males in the spring.

5. E. serotinus: It is an interesting fact that this species, which is seldom encountered in caves, was quite often found here. Like $P$. auritus and $B$. barbastellus, it appears to be a winter species; and in fact, according to Tatarinov (1956), has a high degree of resistance to frost. One of these individuals was not taken into consideration in Fig. 7, since it was exceptionally frequently encountered. This specimen, similarly to certain specimens of $P$. auritus, 
was completely unalarmed when woken, and returned to exactly the same place from which it had previously been removed. This species is also interesting by reason of the small intervals of time between captures of the same individual; also, it has never yet happened that an individual encountered in one season was captured in the next. This constitutes a basic difference in relation to all the other species in this cave.

6. M. dauhentoni: This is a very common species in Pulawy ( $\mathrm{Krz}$ a nows k i, 1956a) but is nevertheless seldom encountered in the cave. It was commoner here only during the season 1952/3: of a total of 23 encounters as many as 14 took place in this season (Fig. 8). The reason for its rarity is not clear, since it belongs to the cave bats ( $\mathrm{F}$ is e $\mathrm{n}$ tr a u t, 1937; B e ls, l. c.).

7. M. mystacinus: Appears to occur in small numbers only in $\mathrm{Pu}-$ lawy, and perhaps for this reason is also rare in the cave. I do not consider that the low winter temperatures in this hidingplace kept it away, because it occurs high up in the Tatra caves (Kowalski, 1953) and in the north crosses the Polar circle (R ybe r g, 1947).

8. Remaining species: P. pipistrellus is known as a typical „tree” species, and is only exceptionally encountered in caves ( $\mathrm{H}$ a a g e $\mathrm{n}$ and $\operatorname{ArnoJd}, 1955)$. It is therefore only encountered here by chance, although it is very common in Puławy. M. bechsteini, the rarest Polish bat, is not numerous at Puławy, although according to $\mathrm{Kuzjak}$ in (1950) it was formerly fairly common here. M. dasycneme is not very frequently met at Puławy, and this is perhaps why it is only exceptionally encountered in this cave: but even so its infrequency in this hiding-place is unexpected.

\section{SUMMARY}

As a result of investigations over a period of five years on the winter bat fauna in an artificial cave at Puławy, a total of 666 individuals, belonging to 10 species, was found; they gave a total of 1234 encounters. My findings are as follows:

1. The composition of bat fauna in the cave under investigation is subject, between October and April (the biological winter of bats) to quantitative and qualitative defined variations which are repeated in successive years. 
2. Each of the species examined (this refers to species more frequently encountered) exhibits characteristic winter dynamics, which usually follow a separate course for each sex. Quantitative sex-ratios are subject to considerable and characteristic fluctuations in the period examined, from October to April.

3. Quantitative and qualitative variations in the composition of tat fauna in the Puławy cave are the result of their flights. These take place throughout the entire winter with the exception of periods of severe frosts.

4. In view of the great variations in the quantitative sex-ratio for the various species, the results of research on the composition cf the quantitative sex composition of bats must be regarded as questionable.

\section{Biological Laboratory in Puławy,}

Institute of Experimental Biology

of the Polish Academy of Sciences.

\section{REFERENCES}

1. Bels, L. - Fifteen years of bat banding in the Netherlands. Publ. natuurhist. Genootsch. Limburg, Vol. 5: 1-99. Maastricht, 1952.

2. Eisentraut, M. - Die deutschen Fledermäuse. 184 pp., P. Schöps, Leipzig, 1937.

3 Hagen, G. and Arnold, J. - Zur Uberwinterung von Pipistrellus pipistrellus (Schreber, 1774). Säugetierk. Mitt., Vol. 3, 3: 122. Stuttgart, 1955 .

4. Kowalski, K. - Materiały do rozmieszczenia i ekologii nietoperzy jaskiniowych w Polsce. Fragm. Faun. Mus. Zool. Polon., Vol. 6, 21: 541567. Warszawa, 1953.

5. Kowalski, K., Krzanowski, A. \& Wojtusiak, R. - Sprawozdanie $z$ akcji obrączkowania nietoperzy w Polsce w latach 1939-1953. Acta Theriol., Vol. 1, 5: 109-158. Warszawa, 1957.

6. Krzanows ki, A. - Nietnperze Puław. Wykaz gatunków i uwagi biologiczne. Acta Theriol., Vol. 1, 4: 8i-108. Warszawa, 1956a.

7. Krzanowski A., Puławska Stacja Terenowa Zakładu Ekologii PAN. Kosmos, A, Vol. 5, 4/21: 508-510. Warszawa, 1956b.

8. Kuzjakin, A. P. - Letučije myši. 444 pp., Sov. Nauka. Moskva, 1950.

9. Mohr, Ch. E. - A survey of bat banding in North America, 1932-1951. Americ. Caver, Vol. 14: 3--12. Trenton, 1952.

10. Nieuwenhoven, P. J. Van - Erological observations in a hibernation quarter of cave dwelling bats in South-Limburg. Publ. natuurhist. Genootsch. Limburg, Vol. 9: 1-55. Maastricht, 1956. 
11. Pa nowicz, F. - Klimat Puław za okres 1872-1941. Pam. Państw. Inst. Nauk. Gosp. Wiejsk., Vol. 19: 69-95. Warszawa, 1949.

12. R y ber g, O. -- Studies on bats and bat parasites. $330 \mathrm{pp}$., Svensk Natur. Stockholm, 1947.

13. Tatarinov, K. A. - Zviri zachidnich oblastej Ukraini. 29-62, AN URSR. Kiiv, 1956.

14. W a łecki, A. - Fauna zwierząt ssących Warszawy i jej stosunek do fauny całego kraju. Pam. Fizjograf., Vol. 1: 268-291. Warszawa, 1881.

EXPLANATION OF FIG. 2

Dotted - individual met with once only,

Black - individual met with at least twice,

Mere line at the base of diagram - visit without any result.

\section{EXPLANATION OF PLATE}

Plate IV.

Phot. 1. Large chamber at lower entrance to cave.

Phot. 2. View of some of the crevices in cave.

\section{STRESZCZENIE}

Jako rezultat pięcioletnich badań nad zimową dynamiką nietoperzy w sztucznej jaskini w m. Puławy, znaleziono łącznie 666 osobników, należących do 10 gatunków (Tabela 1). Dały one w sumie 1234 spotkania. Autor stwierdza co następuje:

1. Skład fauny nietoperzy w badanej jaskini, ulega określonym, ilościowym i jakościowym zmianom, w okresie od października do kwietnia (biologiczna zima nietoperzy), powtarzającym się w kolejnych latach.

2. Ilościowe $\mathrm{i}$ jakościowe zmiany $\mathrm{w}$ składzie fauny nietoperzy $\mathrm{w}$ jaskini purawskiej są wynikiem ich przelotów, które mają miejsce w ciągu całej zimy z wyjątkiem okresów silnych mrozów.

3. Każdy z badanych gatunków wykazuje charakterystyczną dynamikę zimową, odrębną dla obu płci. W okresie tym, stosunki ilościowe samców do samic ulegają znacznym wahaniom (Ryc. 3-7).

4. W związku ze stwierdzeniem istotnych zmian w ilościowym stosunku płci u poszczególnych gatunków, stawia się pod znakiem zapytania dotychczasowe wyniki badań nad tym zagadnieniem $u$ nietoperzy.

Państwowe Wydownictwo Naukowe * Warszawa 1959 r. Nakład 1505 egz. Ark. wyd. 1,14. Maszynopis otrzym. 3.VII.59 r. Podpisano do druku 30.IX.1959 r. Druk ukończono 15.X.1959 r. Pap. druk. sat. k1. III. 80 g. Format B-1.

Bialostockie Zakłady Graficzne. Zam. 2010. * P- Cena 6 zł. 

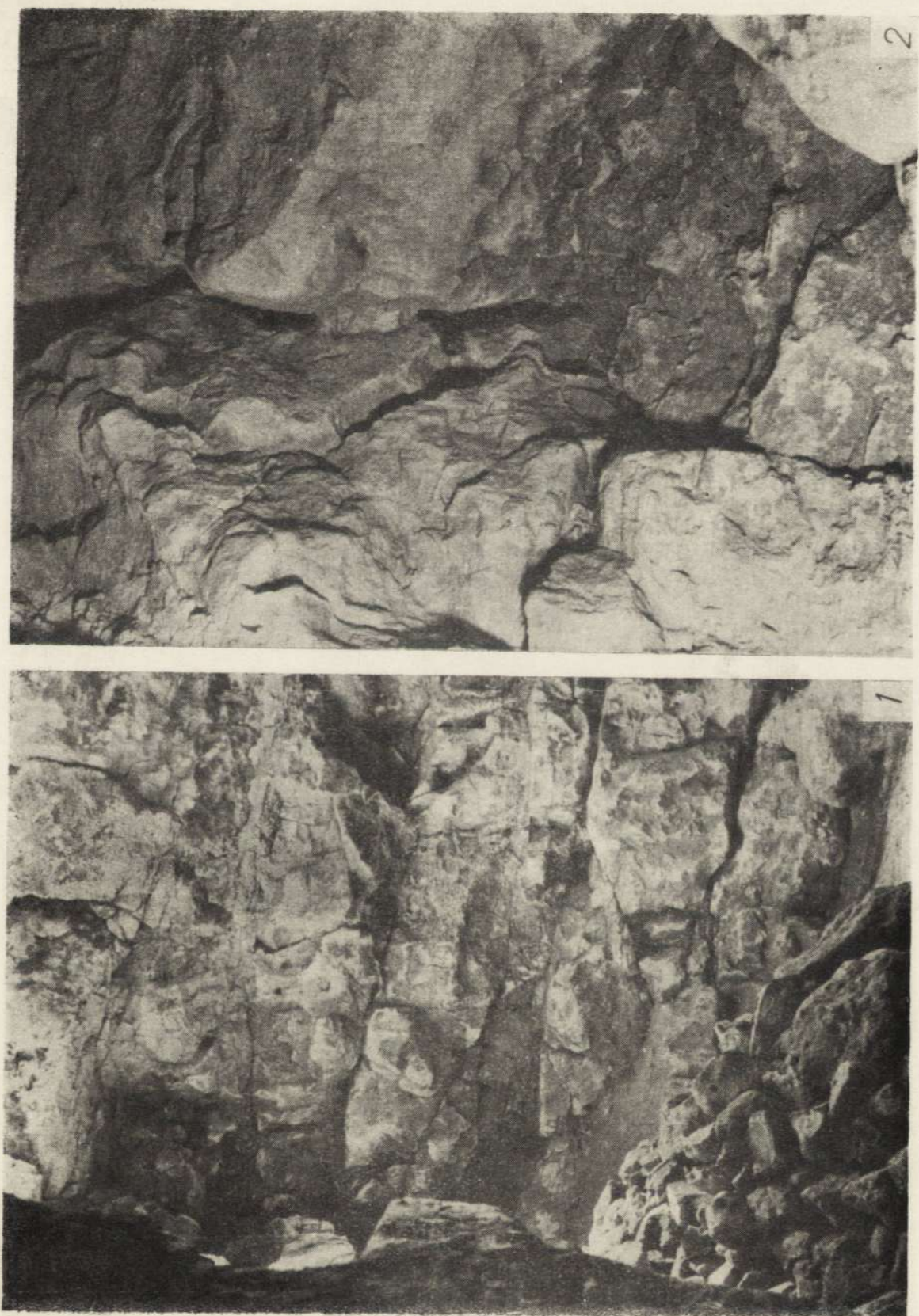

Adam K̄rzanowski 
BIBLIOTEKA

Instytutu Biologii Ssaków

Polskiej Akademii Nauk

$\mathrm{NrCz} .40 .2$ 